\title{
The effect on the BTD of IFRS adoption and the end of the Transitional Tax Regime (RTT) in Brazil
}

\author{
Claudio Marcio Pereira da Cunha ${ }^{1}$ \\ (D) https://orcid.org/0000-0002-2350-0118 \\ Email: claudio.cunha@ufes.br \\ Pedro Paulo Furbino Bretas Barros ${ }^{2}$ \\ (D) https://orcid.org/0000-0002-6152-9456 \\ Email: pedropaulo@ciclo.rec.br \\ ${ }^{1}$ Universidade Federal do Espírito Santo, Departamento de Administração, Vitória, ES, Brazil \\ ${ }^{2}$ Independent researcher not currently affiliated to any academic institution, São Paulo, SP, Brazil
}

Received on 01.19.2021 - Desk acceptance on 02.08.2021 - $2^{\text {nd }}$ version approved on 06.23.2021

Editor-in-Chief: Fábio Frezatti

Associate Editor: Eliseu Martins

\begin{abstract}
This paper aimed to evaluate the moderation by variables related to incentives for earnings management (indebtedness, profitability, and size) over the effect of the change in standards (accounting or tax) on the book-tax differences (BTD). The end of the Transitional Tax Regime (RTT) enables us to evaluate the symmetry between the divergence and reconvergence of the accounting and tax standards, helping to identify the moderating effect of characteristics such as size, leverage, and profitability over the use of the discretion allowed by the International Financial Reporting Standards (IFRS). Studying the effects of changes in the standards contributes to understanding how they affect accounting information quality, particularly when we observe symmetrical movements of divergence of the accounting and tax standards, such as IFRS adoption, and of reconvergence, with the end of the RTT. The analysis conducted enables us to separate effects of divergence between the tax and accounting standards from the innovations introduced by the IFRS. An understanding of the effect of the standard over accounting information quality contributes to the quality of the work of financial analysts, tax authorities, and regulators. Event studies are conducted to evaluate the effect of IFRS adoption, as well as the end of the RTT, over the BTD (a proxy for earnings management), in cross sections of companies. We use explanatory variables related to incentives to manage book and taxable income (indebtedness, profitability, and size), which could explain the ambiguity of the results in the literature. The article provides evidence that the indebtedness and size of companies influence the effect of IFRS adoption, as well as of the end of the RTT. We observed a negative relationship of indebtedness and size with the impact of changes in standards over differences between book and taxable income (BTD).
\end{abstract}

Keywords: book-tax differences, BTD, IFRS, earnings management, incentives. 


\section{INTRODUCTION}

The adoption of the International Financial Reporting Standards (IFRS) significantly altered accounting practice in Brazil. According to CPC 00 (Accounting Pronouncements Committee, 2008), entitled "Conceptual Structure for Elaborating and Disclosing AccountingFinancial Reports," the aim of the IFRS is to provide useful economic information to different types of users for decision making. By means of Normative Instruction 457 (CVM, 2007), the Brazilian Securities and Exchange Commission (CVM) says that the aim of IFRS adoption is to increase the transparency and reliability of financial information, as well as to reduce the cost of external financing sources, for Brazilian companies.

According to Barth et al. (2008), in order to improve accounting information quality, the new standards should be based on defined principles to reflect the company's performance and economic situation. However, they note that the greater flexibility inherent to the principles-based standards could give firms an opportunity to manage earnings.

There is a lack of consensus in the literature regarding whether IFRS adoption has improved or undermined accounting information quality. Bartov et al. (2005), Hung and Subramanyam (2007), Barth et al. (2008), and Horton et al. (2013), for example, provide evidence of an improvement in accounting information quality with IFRS adoption. On the other hand, authors such as Jeanjean and Stolowy (2008), Ahmed et al. (2013), and Capkun et al. (2016) find evidence of an increase in earnings management. So has IFRS adoption contributed to an improvement in accounting information quality or has it enabled its deterioration? What could explain this divergence in the literature regarding the effects of the IFRS on accounting information quality?

This study follows the assumption of Christensen et al. (2007) that companies are subject to different incentives to use the discretion provided by the IFRS, sometimes to improve accounting information and sometimes to favorably distort earnings. The divergent results observed in the literature may thus be due to the effects of the IFRS not being the same for all companies. According to Daske et al. (2008), the benefits of IFRS adoption to the capital market basically occurred for companies that voluntarily adopted them and in countries in which the government is more engaged in legal enforcement. This indicates self-selection bias, where benefits of the IFRS are linked to companies with greater incentives to publish better quality accounting information. On the other hand, there may also be incentives to use the discretion of the IFRS to distort accounting information, for example to improve the indicators used as covenants in debt contracts. In fact, Ball et al. (2015) show that debt contracts anticipated the possibility of this opportunistic use of the greater flexibility after IFRS adoption and reduced their use of financial covenants, in exchange for non-financial covenants.

In this study, the evaluation of the assumption that companies' incentives influence the effect of IFRS adoption over accounting information quality is carried out based on the particularity that in the Brazilian market there was a lag between IFRS adoption for reports meant for the capital market and the corresponding adaptation of the tax standards. The new accounting standards for the capital market became obligatory as of 2010 , while the adaptation of the tax standards was only consolidated in 2014. Between IFRS adoption and tax standard adaptation, companies were subject to the Transitional Tax Regime (RTT). This period created the possibility of greater divergence between book and taxable income. These differences between book and taxable income are called book-tax differences (BTDs) in the literature. Morais and Macedo (2021) recently showed that, in Brazil, the BTD captures the discretionary actions of managers related to earnings management via accounting decisions.

According to Desai (2005), the distinction between book and taxable income enables managers to undervalue earnings for the tax authorities, while at the same time inflating the earnings presented to the capital market. This would explain the reduction in taxable income at the same time that the book income of publicly-traded companies in the United States increased in the 1990s. More profitable companies therefore have an incentive to increase the difference (BTD) between book income and taxable income. According to Zimmerman (1983), bigger companies are more subject to scrutiny by the tax authorities and have an incentive to take advantage of the flexibility of the accounting standards to reduce the BTD. Mills and Newberry (2005) report that more leveraged firms with a worse evaluation by rating agencies tend to present a greater divergence between book income and taxable income.

The aim of this study is to evaluate the moderation by the indebtedness, profitability, and size variables over the effect of IFRS adoption on the differences between book and taxable income (BTD). Event studies are carried out, aiming to take advantage of the opportunities of the 
lag in Brazil between the adjustment to the IFRS of the accounting standards (2010) and that of the tax standards (2014). Specifically, we evaluate whether the effect of IFRS adoption and of the end of the RTT over the BTD are influenced by the profitability, size, and indebtedness variables, which would be related with incentives for companies to manage earnings.

This article contributes with a new approach for evaluating the effect of changes in the accounting and tax standards over information quality. The approach departs from the dichotomy between the improvement or deterioration of information quality, arguing that the use of flexibility depends on the incentives that companies are subject to. Empirically, two event studies are conducted, using the lag between the changes in the accounting standards (2010) and tax standards (2014), to evaluate how different incentives affect the BTD during the standard changes.

\section{THEORETICAL FRAMEWORK}

\subsection{The Changes with IFRS Adoption}

As of 2010, Brazilian companies subject to Law n. 6,404, of December $15^{\text {th }}$ of 1976 (Brazilian Corporation Law), have been obliged to recognize, measure, and publish accounting information according to the international standards (IFRS). The adoption of the new standards was facultative as of 2007 and has been obligatory since 2010, via Law n. 11,638 , of December $28^{\text {th }}$ of 2007 , and Law n. 11,941, of May $27^{\text {th }}$ of 2009 , the latter of which defined the RTT. The RTT determined that the adoption of the new accounting methods should not affect the calculation of earnings for tax purposes. The transitional regime lasted until 2014, when it was altered by Law $\mathrm{n}$. 12,973, of May $13^{\text {th }}$ of 2014.

The main change that the IFRS brought, according to Barth et al. (2008), was to give more importance to principles, thus being more flexible than rulesbased standards. Contributing to the adoption of the international standards was the possibility of greater comparability of company financial information (Joia \& Nakao, 2014, p. 23).

According to Cavalier-Rosa and Tiras (2013), in Brazil there has been a change from an accounting system focused on tax effects to one focused on information for investors, similarly to in the biggest global economies. Joia and Nakao (2014, p. 23) say there has been a neutralization of tax accounting, reducing its impact on financial accounting.

It is possible to divide the main changes between recognition, measurement, and disclosure. Among the changes in recognition introduced by the Accounting Pronouncements Committee (CPC), we can highlight recognition only for items that will probably bring future economic benefits to the entity, besides it being possible to reliably measure their cost (Accounting Pronouncements Committee, 2008, item 4.38). CPC 06 (Leasing Operations) regulated the recognition of financial leasing assets and liabilities. CPC 01 (Reducing the Recoverable Value of Assets) introduced the concept of impairment, regulating the reduction of asset values. CPC 04 (Intangible Assets) restricts the recognition of some research and development assets.

With relation to measurement, CPC 14 (Financial Instruments) defines the measurement of financial instruments using market value. CPC 12 (Present Value Adjustment) defines that transactions carried out in installments should be measured at present value. CPC 46 (Fair Value Measurement), in turn, introduces the concept of fair value, using the value attributed by the market, when available, for measuring.

As CPC 00 (Conceptual Structure for Elaborating and Disclosing Accounting-Financial Reports) states that essence over form is an indispensable banner of the International Accounting Standards Board (IASB), we can infer that the IFRS enable more accountant judgement or greater flexibility in applying the standards, as proposed by Barth et al. (2008). For example, Mendes and Freire (2014) indicate that, due to the number 13 IFRS (Fair Value Measurement), there are increasing degrees of subjectivity with the level of fair value assessment applied to liabilities and assets, due to the comparability with prices in an active market. Thus, it is possible that the greater flexibility given by the new rules has been used to manage earnings.

\subsection{IFRS and Accounting Information Quality}

According to the CVM, via Normative Instruction 457 (2007), the aim of IFRS adoption is to increase the transparency and reliability of financial information, as well as to reduce the cost of external financing sources, for Brazilian companies. These objectives are aligned with those that guided IFRS adoption in the European 
Union, as reported, for example, by Daske et al. (2008). Particularly with relation to accounting information quality, there are different ways of evaluating it, such as by analyzing discretionary accruals, value relevance, income smoothing, timely loss recognition, and differences between book and taxable income (book-tax difference, or BTD).

The initial analyses indicated an improvement in accounting information quality with IFRS adoption. For example, Bartov et al. (2005) and Hung and Subramanyam (2007) show that, in Germany, the adoption of the International Accounting Standards (IAS), standards that precede the IFRS, increased the value relevance for stock prices. Barth et al. (2008) report evidence that the introduction of the IAS reduced earnings management and increased the value relevance of accounting information (earnings and net equity) for stock prices in 22 countries, for companies that adopted the international standards between 1994 and 2003.

Subsequent studies, however, have indicated that these initial results may be due to other factors. For example, Daske et al. (2008) and Christensen et al. (2015) relate the positive effects of IFRS adoption with the voluntary adoption of these new standards, indicating that selfselection bias in the sample may have influenced the initial results.

Besides the self-selection problem, the country's legal environment may interfere in the influence of the IFRS over accounting information quality, as shown by Daske et al. (2008), Horton et al. (2013), Christensen et al. (2013), and Jeanjean and Stolowy (2008).

Santos and Cavalcante (2014) analyze IFRS adoption in Brazil in the period from 1999 to 2013. They identified an increase in the value relevance of earnings in pricing, but a reduction in timely loss recognition. Macedo et al. (2013) also identify an increase in the value relevance of net income after IFRS adoption, but not of net equity, which would be expected with the changes in the measurement and recognition of assets and liabilities. Grecco (2013) and Joia and Nakao (2014) find no evidence of a reduction in earnings management in Brazilian companies after IFRS adoption, unlike Grecco et al. (2014). These studies are essentially based on the same sample, including all companies listed on the São Paulo Stock, Commodities, and Futures Exchange (BM\&FBovespa) in the period from 2006 to 2011, covering between 274 and 361 companies, depending on the exclusions made. Using a sample of only 93 companies, from among the most liquid ones on the BM\&FBovespa, with data covering the period from 2000 to 2011, Silva and Nardi (2017) find evidence of a reduction in earnings management, an increase in timely loss recognition, and an increase in the value relevance of earnings. Taken together, these signs are contradictory regarding the increase in accounting information quality and show possible dependence on the variables and the sample considered.

\subsection{BTD and Accounting Information Quality}

According to Dechow (1994), book income is measured using the accruals basis and employed as a measure of company performance. According to Desai (2005), taxable income, in turn, emphasizes real revenues and real expense payments, at the time they are realized, a distinction that would enable managers to undervalue earnings for the tax authorities while at the same time inflating the earnings presented to the capital market. This would explain the simultaneous reduction in taxable income and increase in book income of publicly-traded companies in the USA in the 1990s. Nakao and Gray (2018) emphasize that, in Brazil, there was greater divergence between the new mandatory accounting standards (IFRS) and the tax standards between 2010 and 2014 .

According to Atwood et al. (2012), the executives of organizations have incentives both to increase company earnings, and to reduce the taxes paid. Consistently with this assumption, Hanlon (2005) identifies that the high value for the BTD can be seen as a low market expectation of company earnings persistence, related with non-recurrent items. Analyzing a sample of 580 publiclytraded companies in Latin America in the period from 2002 to 2013, Marques et al. (2016) show that the higher the BTD, the lower the future earnings.

Badertscher et al. show that the BTD has predictive power regarding the adjustments in the resubmission of income statements, analyzing a sample of 214 financial statements resubmitted between 1997 and 2002 in the USA. Ferreira et al. (2012) identify a directly proportional relationship between the BTD value and the value of discretionary accruals in Brazil in the period from 2005 to 2009 .

Taking advantage of particularities of the Chinese legislation, Tang and Firth (2011) identify indicators that show incentives for companies to manage earnings: the tax rate applicable to each company, the quantity of different rates for each entity, if the entity has the right to issue securities, if it had a loss in the current year, and if it is controlled by the government. The study reports that the higher the tax rate and the greater the number of rates to be used, the higher the BTD, which is consistent with taxable earnings management, aiming to reduce them. It also shows that, if the company had losses, there was an increase in the BTD, which is consistent with accounting earnings management to increase them. 
If BTD has predictive power regarding earnings, Mills (1998) shows that it is also related with the actions of the tax authorities. In particular, the author presents evidence that in the USA between 1982 and 1992, the higher the BTD, the lower the probability of the company being audited by the Internal Revenue Service (IRS) and the greater the adjustment in the tax statement proposed by the IRS, that is, the greater the scrutiny of the tax inspection authorities, which companies tend to avoid. Chan et al. (2010) show that the result of Mills (1998) is also valid for China in the period from 1996 to 2003. They also show, however, that this relationship decreases as the accounting and tax standards diverge. Analyzing a sample of 59 companies accused by the American government of tax evasion, regarding the fiscal years from 1975 to 2002, Wilson (2009) identifies a positive relationship between the BTD and the probability of the company being accused, in a comparison with companies of comparable sizes or sectors.

In a sample of 34 countries, Blaylock et al. (2015) verify that the closer the accounting and tax standards (book-tax conformity), the higher the level of earnings management. From this perspective, an increase in the BTD can indicate an improvement, rather than deterioration, in information quality, particularly when there is divergence between the accounting and tax standards, as was the case of Brazil under the RTT.

Chan et al. (2010) propose that, when there is conformity between the accounting and tax standards, earnings management aiming to reduce tax payments leads to informational costs, due to the simultaneous adjustment of book income, mitigating tax management practices. However, with the divergence between the standards, these informational costs are suppressed, which would stimulate tax management. They show that with IFRS adoption in China in the period from 1996 to 2003, which resulted in a reduction in conformity between the accounting and tax standards, there was an increase in the adjustments requested by the tax authorities (tax noncompliance). On the other hand, the relationship between the requested adjustments and the BTD decreased.

Consistently with Chan et al. (2010), in a study involving 35 countries in the period from 1999 to 2014, with at least 20 countries per country-year, Braga (2017) identified a positive relationship between IFRS adoption and two tax avoidance measures similar to the BTD. The author also identified that these measures are positively influenced by variables related with incentives for tax management, namely the rate of income tax and pre-tax ROA, and negatively correlated with legal enforcement in the country.

\subsection{Variables Related with the Effect of IFRS Adoption}

As seen, the greater flexibility in the application of principles-based standards can both contribute to improving information quality and provide an opportunity for opportunist distortions. Both effects may be present, particularly in the case of mandatory IFRS adoption, as occurred in Brazil. With this, it can be difficult to capture the effect of the IFRS or it may only be partially captured.

The task of evaluating the effect of IFRS adoption over information quality based on the BTD is even more difficult, since, if on one hand a greater BTD has been pointed out as an indication of worse information quality, on the other hand, divergence between the accounting and tax standards would naturally increase the BTD, which could even be associated with an improvement in accounting information quality.

As a way of separating the different effects of IFRS adoption over the BTD, we follow a line of the literature that includes in the analysis variables that can moderate that effect, through their relationship with incentives to use the greater discretion provided.

Hagerman and Zmijewski (1979) propose that the choices in applying the accounting rules, when there is flexibility for this, are guided by the incentives the firm's management is subject to. They argue that bigger and more profitable firms would have an incentive to make accounting choices that reduced earnings, due to the political costs and possible attraction of new competitors, which is supported by empirical evidence.

Christensen et al. (2007) also use the difference in incentives as a basis, specifically to evaluate IFRS adoption. They analyze the effect of mandatory IFRS adoption in the United Kingdom over the cost of own capital, but considering the differences between companies. They take into consideration the incentives to reduce information asymmetry between insiders and other capital market agents. For this, they evaluate the probability of companies in the United Kingdom voluntarily adopting the IFRS, before they became mandatory, if they had that option, considering the similarity with companies that voluntarily adopted the IFRS in Germany, where there was that option. The analysis of the German companies identifies bigger, more indebted companies with greater exposure to the overseas market (higher percentage of revenue in the overseas market over total revenue) as being more likely to voluntarily adopt the IFRS. The article shows a direct relationship between the probability of voluntarily adopting the IFRS and a reduction in the cost of own capital with mandatory IFRS adoption. 
Daske et al. (2013) carry out a similar analysis, using a broader sample. They form a group of companies considered to be seriously committed to the change in accounting practices, choosing bigger companies (according to market value), with greater financial leverage, higher profitability (higher ROA), with greater growth opportunities (higher book-to-market), greater internationalization (revenue in the overseas market over total revenue), and a lower ownership concentration. They show that, for this group, mandatory IFRS adoption increased liquidity and reduced cost of capital, despite there not being a significant average effect, when considering all the companies that mandatorily adopted the IFRS (that is, which did not adopt them in advance).

Analyzing IFRS adoption in Brazil in the period from 2003 to 2014, Black and Nakao (2017) also separate the sample of companies according to the incentives in relation to accounting information quality. However, they highlight a third group, of companies with ADRs, which already elaborated reports in compliance with the international standards. They show that IFRS adoption brought to the group that did not have ADRs, but had incentives to improve information quality (serious compliers), an increase in the value relevance of earnings, an increase in timely loss recognition, and a reduction in earnings management.

Byard et al. (2011) use as a proxy for accounting information quality the average magnitude and dispersion of analysts' forecasting errors. They show that the improvement in accounting information quality after mandatory IFRS adoption is related with incentives for greater transparency, namely: growth opportunities (Tobin's Q), ownership concentration, auditor quality (big 4), profitability (ROA), indebtedness, and internationalization (percentage of revenue derived from the overseas market).

\subsection{Formulation of the Hypotheses}

The articles presented in the previous section show the importance of considering the incentives of companies to use discretion when applying the accounting standards. The most frequently used variables in the articles described are the profitability, the financial leverage (indebtedness), and the size of the firm, and so for that reason we chose to apply them in the present study.

Level of indebtedness is one of the factors that can incentivize earnings management, as observed by Sweeney (1994), according to whom companies that are close to violating loans contracts tend to increase their discretionary accruals. With IFRS adoption,
Hung and Subramanyam (2007) found an increase in assets, which ultimately reduced debt ratios. In a study covering the period from 2001 to 2010, with companies from 43 countries, Ball et al. (2015) showed that after IFRS adoption debt contracts reduced their use of financial covenants, which they attribute to the perception of lower reliability of these indicators, due to the greater discretion in applying the standards. Mills and Newberry (2005) report that more leveraged firms with a worse evaluation by rating agencies tend to present greater divergence between book and taxable income. This evidence supports the idea that more leveraged companies have a greater incentive to declare higher book income. Consistently, Braga (2017) identifies a positive relationship between financial leverage and tax avoidance measures similar to the BTD. Joia and Nakao (2014) show that in Brazil in the period from 2006 to 2011, companies with a higher level of indebtedness presented greater discretionary accruals.

Hypothesis 1: Indebtedness has a positive moderating effect over the BTD when the accounting and tax standards diverge (IFRS adoption) and a negative one when they converge (end of the RTT).

The possibility of paying less tax can be an incentive for earnings management, in the case of taxable earnings. Armstrong, Louin, and Larcker (2012) develop a measure of tax sheltering behavior and show that it is positively correlated with profitability (ROA). Huseynov and Klamm (2012) show that profitability (ROA) is negatively related with the effective income tax rate, calculated based on the income statement elaborated according to the tax standards (US GAAP). Both pieces of evidence indicate greater incentives for more profitable companies to declare lower taxable earnings. Consistently, Braga (2017) identified a positive relationship between pre-tax ROA and two tax avoidance measures similar to the BTD (the author found this relationship to be negative with a tax avoidance measure that uses the generation of operating cash flow, instead of operating profit).

In Brazil, in a study conducted between 2010 and 2015 with 124 publicly-traded Brazilian companies, Fonseca and Costa (2017) show that the BTD, in its nominal value, is positively affected by a dummy variable indicating if the company reported a profit or loss. This finding may imply that companies with a loss manage their accounting earnings in order to present a profit to the capital market, or profitable companies take advantage of the ambiguities of the tax legislation to reduce tax payments. With IFRS adoption, under divergence between the accounting and tax standards, the effects of profitability over the BTD are enhanced. 
Hypothesis 2: Profitability has a positive moderating effect over the BTD when the accounting and tax standards diverge (IFRS adoption) and a negative one when they converge (end of the RTT).

Besides indebtedness and profitability, the size of the company can influence earnings management. Bigger companies are more subject to scrutiny by the tax authorities, as shown by Zimmerman (1983), among others. Moreover, there is a relationship between the BTD and adjustments requested by the tax authority, as shown by Mills (1998), Wilson (2009), and Chan et al. (2010). It can thus be assumed that, ceteris paribus, bigger companies would seek to avoid disclosing a high BTD to try to reduce the attention from the tax authorities. Consistently, Braga (2017) identifies a negative relationship between size and tax avoidance measures similar to the BTD. In Brazil, Ferreira et al. (2012) and Joia and Nakao (2014) show that for bigger companies, discretionary accruals are lower.

Hypothesis 3: There is a negative correlation between size and variations in the BTD when the accounting and tax standards diverge (IFRS adoption) and a positive one when they converge (end of the RTT).

\section{METHODOLOGY}

\subsection{Sample}

The initial sample is formed of all the companies listed on the Bovespa between 2005 and 2019. Companies from the financial sector were excluded, as their financial statements follow another standard; there is less discretion to choose the financial leverage and the direct tax rates are different. Companies with trading in less than $20 \%$ of trading sessions in the year were excluded so that, at any time, the price more adequately reflects investors' updated expectations.

The sample was divided into three periods: from 2005 to 2009, before IFRS adoption; from 2010 to 2014, after IFRS adoption and with the Transitional Tax Regime (RTT); and from 2015 to 2019, after the RTT. The companies that voluntarily adopted the IFRS before the obligatory date were identified using an existing filter in the Comdinheiro database. The period after the end of the RTT was highlighted because the tax standards were altered, which may have affected the BTD. According to Silva et al. (2014), the RTT ensured tax neutrality in the adoption of the IFRS with no effects from alterations in taxation. With the end of the RTT via Law n. 12,973, of May of 2014, the income tax and social contribution on net profit calculation was defined, incorporating modifications in the accounting standard such as fair value adjustment and present value adjustment of assets and liabilities.

\subsection{Description of the Variables}

The dependent variables are defined based on the BTD. According to Ferreira et al. (2012), they measure differences between book income, which is earnings before income taxes (EBIT), and taxable earnings (TE). The BTD calculation is carried out according to Equation (1).

$$
\mathrm{BTD}=\mathrm{EBIT}-\mathrm{TE}
$$

Taxable earnings are, in turn, determined based on the division of the current provision for income tax and the social contribution on net profit (IR and CSLL) by their rate, considering $34 \%$ in this article, as indicated in Equation (2). When the value of the current provision for IR and CSLL was unavailable, we considered the difference between the values of the total provision for IR plus CSLL from the Income Statement (IS) and the deferred IR and CSLL value indicated in the Cash Flow Statement (CFS).

$$
\mathrm{TE}=(\mathrm{IR}+\mathrm{CSLL}) / 34 \%
$$

To neutralize the effect of the difference in scale between the companies, the BTD value was divided by total assets. This way of scaling the BTD is warranted considering that the explanatory variables, described below, are indices usually calculated with total assets as the denominator. For that reason, it is widely used in the literature, for example by Fonseca and Costa (2017).

The indebtedness proxy $\left(\operatorname{Debt}_{\mathrm{i}, \mathrm{t}}\right)$, highlighted by hypothesis 1 as a variable that explains the BTD in the event of IFRS adoption, was defined as the ratio between net debt and total assets. The profitability proxy $\left(R O A_{\mathrm{i}, \mathrm{t}}\right)$, highlighted in hypothesis 2, was defined as the ratio between net earnings and total assets. The size proxy, highlighted in hypothesis 3 , was defined as the logarithm of total assets $\left(\log \left(T A_{i, t}\right)\right)$. As an important part of the changes in the standards relates to the evaluation of assets, it may be that differences in the set of assets represent different impacts. For that reason, the tangibility of assets $\left(\right.$ Tang $\left._{\mathrm{i}, \mathrm{t}}\right)$ was adopted as a control variable, defined as the ratio between fixed assets and total assets. 
The value of each of the aforementioned variables was calculated in each year. The values prior and subsequent to the event (start of the IFRS and end of the RTT) were calculated as the annual mean, using three temporal windows: one year, three years, and five years. Thus, for IFRS adoption, the values prior to the event were: the 2009 value, or the mean value from 2007 to 2009 , or the mean value from 2005 to 2009 . And the values subsequent to the event were: the 2010 value, or the mean value from 2010 to 2012, or the mean value from 2010 to 2014. For the end of the RTT, the values prior to the event were: the 2014 value, or the mean value from 2012 to 2014, or the mean value from 2010 to 2014 . And the values subsequent to the event were: the 2015 value, or the mean value from 2015 to 2017, or the mean value from 2015 to 2019. In the one-year windows we only considered the companies with all the variables available before and after the event. In the three- and five-year windows, we only considered the companies with at least two years of available data both before and after the event. In the case of the company having adopted the IFRS before 2010, the years prior to 2010 with IFRS were ignored in the means calculations.

\subsection{Econometric Model}

One way of evaluating hypotheses 1 and 2 is to address the effects of the changes in the standards as treatment effects and compute the average treatment effect on the treated (ATET), just like Wooldridge (2001, p. 613).

$$
\mathrm{E}[y \mid w, \mathbf{x}]=\gamma_{0}+\alpha w+\mathbf{x}^{\prime} \boldsymbol{\beta}_{0}+w\left(\mathbf{x}^{\prime}-\mathrm{E}[\mathbf{x}]^{\prime}\right) \boldsymbol{\delta}
$$

In Equation (3), $\gamma_{0}, \alpha, \boldsymbol{\beta}_{0}$, and $\boldsymbol{\delta}$ are parameters to be determined. The $\mathbf{x}$ vector contains the control variables, and the $w$ variable is the treatment dummy, which indicates if the observation is of a treated $(w=1)$ or non-treated individual $(w=0)$. The $\alpha$ parameter is the ATET. The term $\mathbf{x}^{\prime} \boldsymbol{\beta}_{0}$ is the effect of the control variables $(\mathbf{x})$, independently of the treatment. The term $w\left(\mathbf{x}^{\prime}-\mathrm{E}[\mathbf{X}]^{\prime}\right) \boldsymbol{\delta}$ is the interaction of the control variables $(\mathbf{x})$ with the treatment dummy $(w)$, that is, it is the moderating effect of the control variables over the treatment. To better understand the meaning of that moderating effect, by highlighting the dummy $w$ in both terms in which it appears, it can be said that the amplified treatment effect would be the sum of $\alpha+\left(\mathbf{x}^{\prime}-\mathrm{E}[\mathbf{x}]^{\prime}\right) \boldsymbol{\delta}$. In this amplified treatment effect, the $\boldsymbol{\alpha}$ parameter is the average effect of the treatment on the sample, and the $\boldsymbol{\delta}$ parameter captures the variations in the effect of the treatment derived from the differences between the individuals, which are reflected in the $\mathbf{x}$ control variables. Thus, the $\boldsymbol{\delta}$ parameter captures the variations that $\mathbf{x}$ cause in the treatment $(w=1)$, which is called moderation. In this study we are interested in the vector of coefficients $\boldsymbol{\delta}$.

The regression of Equation (3), however, has some problems. First, $\mathrm{BTD}_{0}(y$ of $w=0)$ is calculated with $\mathrm{ROA}_{0}$ (one of the variables of the $\mathbf{x}$ vector of $w=0$ ). If $\mathrm{ROA}_{0}$ is determining the dependent variables and it is an explanatory variable $(\mathbf{x})$, there is a simultaneity problem. Debt ${ }_{0}$ is also influenced by $\mathrm{ROA}_{0}$, in that there is also simultaneity between $\mathrm{BTD}_{0}$ and $\mathrm{Debt}_{0}$. Another problem is that there is autocorrelation of BTD. Thus, the unexplained deviations in $\mathrm{BTD}_{0}$ would be correlated with the values of $\mathrm{BTD}_{1}$, invalidating the hypothesis of strict exogeneity of the regression model. To overcome these problems, we observed that $\mathrm{E}[y \mid w=0, \mathbf{x}]=\gamma_{0}+\mathbf{x}^{\prime} \boldsymbol{\beta}_{0}$. Substituting in Equation (3), we obtain Equation (4).

$$
\mathrm{E}[y \mid w, \mathbf{x}]=\gamma_{0}+\mathrm{E}[y \mid w=0, \mathbf{x}]+w\left(\mathbf{x}^{\prime}-\mathrm{E}[\mathbf{x}]^{\prime}\right) \boldsymbol{\delta}
$$

If the objective was to evaluate the average effect of IFRS adoption, Equation (4) would be useless, as it does not contain the $\alpha$ parameter. However, our interest is in the moderating effect of the $\mathbf{x}$ variables, which is evaluated using the vector of coefficients $\delta$. The analysis can thus be based on Equation (5), in which $\eta=\gamma_{0}+E[\mathbf{x}] \boldsymbol{\delta}$.

$$
y(w=1, \mathbf{x})=\eta+\hat{y}(w=0, \mathbf{x})+\mathbf{x}^{\prime} \boldsymbol{\delta}+u
$$

One candidate for $\hat{y}(w=0, \mathbf{x})$ is the $y$ of the company before the "treatment," that is, before IFRS adoption or before the end of the RTT, which we will call $y_{\mathrm{t}-1}$. However, shocks may have occurred in the environment that affected $y$, meaning that $y_{\mathrm{t}-1}$ is a biased measure of $\hat{y}$. So, instead of using $\hat{y}=y_{\mathrm{t}-1}+e$, we assume that $\hat{y}=\phi_{0}+\phi_{1} y_{\mathrm{t}-1}+v$. This enables us to capture the persistence effect of the $y$ variable, indicated by the coefficient $\phi_{1}$, and the shocks in the environment that are common to all companies, captured by the intercept $\phi_{0}$. Substituting $\hat{y}$ in (5), we obtain Equation (6), in which $\rho=\eta+\phi_{0} ; e=u+v$.

$$
y=\rho+\phi_{1} y_{t-1}+\mathbf{x}^{\prime} \boldsymbol{\delta}+e
$$

To verify hypotheses 1 and 2 , the cross sectional model given by Equation (6) was used, where the dependent variable is the ratio between the BTD and total assets $\left(B T D_{\mathrm{i}, \mathrm{t}}\right)$, both evaluated after the event (start of the IFRS and end of the RTT), as represented in Equation (7). Of the explanatory variables, Debt $t_{i,-1}$ is the company's indebtedness, evaluated as the ratio between net debt and total assets; $R O A_{\mathrm{i}, \mathrm{t}-1}$ is the company's ROA, evaluated as the ratio between net income and total assets; Tang $_{\mathrm{i}, \mathrm{t}-1}$ is the tangibility of assets, evaluated as the ratio between fixed assets and total assets; and $B T D_{\mathrm{i}, \mathrm{t}-1}$ is the $\mathrm{BTD}$ value divided by total assets, evaluated in the period prior to the event $(t-1)$, just like the other explanatory variables.

$$
B T D_{i, t}=\rho+\phi_{1} B T D_{i, t-1}+\delta_{1} \operatorname{Debt}_{i, t-1}+\delta_{2} R O A_{i, t-1}+\delta_{3} \operatorname{Tang}_{i, t-1}+e_{\mathrm{i}}
$$


The absolute value of BTD was also used as a dependent variable, as described in Equation (8), to verify if the divergence between the accounting and tax standards, with IFRS adoption, did in fact cause an increase in the divergence between book and taxable income (increase in the absolute value of BTD), as well as if there was a

$$
\operatorname{Abs}\left(B T D_{\mathrm{i}, \mathrm{t}}\right)=\rho+\phi_{1} A b s\left(B T D_{\mathrm{i}, \mathrm{t}-1}\right)+\delta_{1} \operatorname{Debt}_{i, t-1}+\delta_{2} R O A_{i, t-1}+\delta_{3} \operatorname{Tang}_{i, t-1}+e_{\mathrm{i}}
$$

In the models described by equations (7) and (8), it is not appropriate to include a size proxy, as the variables are scaled through dividing by total assets, which is a proxy for size.

Thus, to test hypothesis 3 , which is specific to the size effect, we chose as a dependent variable the logarithm of the ratio between the absolute values of BTD after and before the event, for each one of the events (start of the IFRS and end of the RTT). This variable is an index that is not directly affected by the company's size,

subsequent reduction in that divergence, with the end of the RTT. In Equation (8), the variables are essentially the same as in Equation (7), except for the use of the absolute value of BTD, both after (dependent variable) and before (control variable) the event.

enabling the use of size as an explanatory variable for variations derived from management choices. On the other hand, as the previous BTD $\left(B T D_{\mathrm{i}, \mathrm{t}-1}\right)$ is a function of net profit, it is directly related with $R O A_{\mathrm{i}, \mathrm{t}-\mathrm{l}}$, which would create an endogeneity problem if this was employed as an explanatory variable. This model is represented in Equation (9), in which $S_{i z e_{\mathrm{i}}}$ is the proxy for company size, evaluated as the logarithm of total assets, Debt $t_{\mathrm{i}, \mathrm{t}-1}$ and Tang $_{\mathrm{i}, \mathrm{t}-1}$ were defined previously, and $R O A_{\mathrm{i}, \mathrm{t}-1}$ was not included to avoid any endogeneity problem.

$$
\log \left(\frac{A b s\left(B T D_{i, t}\right)}{\operatorname{Abs}\left(B T D_{i, t-1}\right)}\right)=\alpha+\beta_{1} \operatorname{Debt}_{i, t-1}+\beta_{2} \text { Size }_{i, t-1}+\beta_{3} \text { Tang }_{i, t-1}+u_{i}
$$

\section{RESULTS IN THE EVENT OF IFRS ADOPTION}

Table 1 presents the descriptive statistics for the periods before and after the IFRS adoption event. As previously described, the values used in the analyses are the means of the annual values, considering one-, three-, and fiveyear windows. There is no evident variation in the BTD between the periods before and after the event based on the descriptive statistics.
We also observe that the average indebtedness roughly doubles between the periods before and after the event. As we used the values before the event for the explanatory variables, in order to avoid endogeneity problems in the regressions, these values may not adequately reflect the value of the variable in the event.

Table 1

\begin{tabular}{|c|c|c|c|c|c|c|c|}
\hline \multirow[b]{2}{*}{ Variable } & \multirow[b]{2}{*}{ Statistic } & \multicolumn{2}{|c|}{ One-year window } & \multicolumn{2}{|c|}{ Three-year window } & \multicolumn{2}{|c|}{ Five-year window } \\
\hline & & Pre-IFRS & Post-IFRS & Pre-IFRS & Post-IFRS & Pre-IFRS & Post-IFRS \\
\hline \multirow{2}{*}{ BTD } & mean & 0.009 & 0.010 & 0.002 & 0.003 & 0.001 & 0.000 \\
\hline & st. dev. & 0.027 & 0.038 & 0.021 & 0.017 & 0.018 & 0.021 \\
\hline \multirow{2}{*}{ Debt } & mean & 0.070 & 0.125 & 0.062 & 0.162 & 0.056 & 0.181 \\
\hline & st. dev. & 0.275 & 0.241 & 0.211 & 0.188 & 0.203 & 0.193 \\
\hline \multirow{2}{*}{$\mathrm{ROA}$} & mean & 0.084 & 0.103 & 0.079 & 0.079 & 0.082 & 0.073 \\
\hline & st. dev. & 0.101 & 0.189 & 0.077 & 0.065 & 0.076 & 0.073 \\
\hline \multirow{2}{*}{ Tang } & mean & 0.302 & 0.248 & 0.304 & 0.248 & 0.307 & 0.242 \\
\hline & st. dev. & 0.228 & 0.217 & 0.225 & 0.207 & 0.220 & 0.203 \\
\hline \multirow{2}{*}{$\log (\mathrm{TA})$} & mean & 21.615 & 21.855 & 21.564 & 22.042 & 21.462 & 22.066 \\
\hline & st. dev. & 1.540 & 1.519 & 1.400 & 1.438 & 1.475 & 1.517 \\
\hline
\end{tabular}

Descriptive statistics in the periods before (Pre) and after (Post) the IFRS adoption event

Note: BTD is the book-tax difference, calculated as the difference between earnings before income tax (EBIT) and taxable earnings, divided by total assets; Debt is the proxy for indebtedness, calculated as the ratio between net debt and total assets; ROA is the proxy for profitability, calculated as the ratio between net income and total assets; Tang is the proxy for tangibility of assets, calculated as the ratio between fixed assets and total assets; $\log (T A)$ is the proxy for size, calculated as the logarithm of total assets. Source: Elaborated by the authors. 
Table 2 shows an increase in the absolute value of the BTD after IFRS adoption in Brazil, through the positive and statistically significant value (in the one- and five-year windows) of the intercept $(\alpha)$ of the regressions. This was expected given the divergence that occurred between the standards geared toward the capital market and the tax standards. Table 2 also shows that, after IFRS adoption, indebtedness has a negative moderating effect over the absolute value of the BTD. This result refutes hypothesis 1 .
Instead of artificially increasing book income, increasing the absolute value of the BTD, the IFRS may have induced greater transparency, with new rules about recognizing losses and measuring assets. But more indebted companies already had an incentive to be more transparent. The results of Braga (2017) and Joia and Nakao (2014) indicate that the divergence between book and taxable income is greater in Brazil for more indebted companies. However, this effect would not have been amplified by IFRS adoption.

Table 2

Result of the regression, for the IFRS adoption event, of the model given by Equation (9)

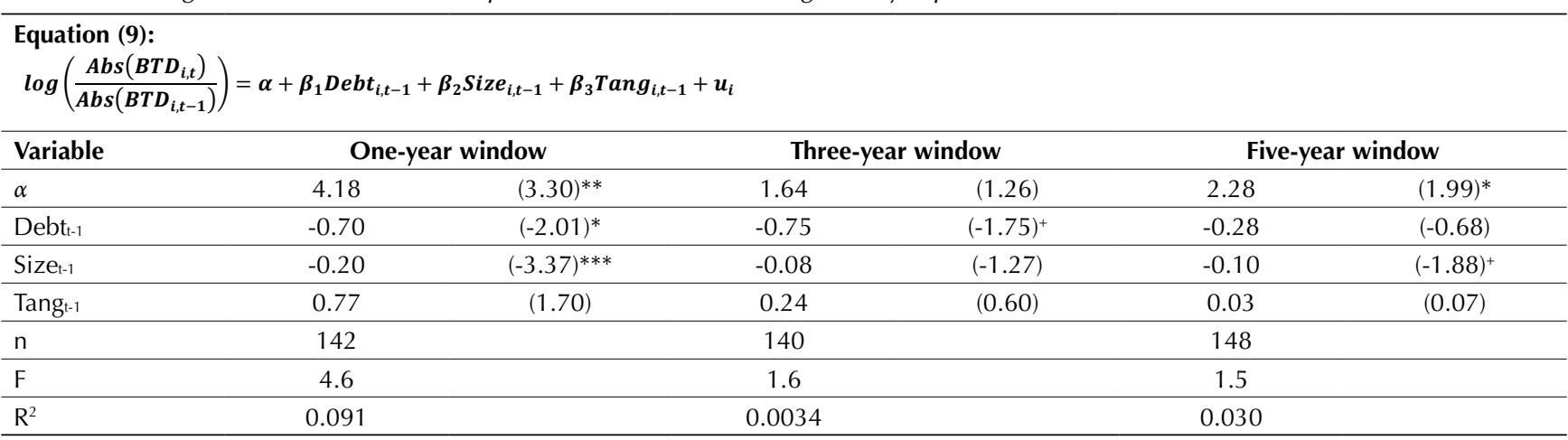

Note: BTD is the book-tax difference, calculated as the difference between earnings before income tax (EBIT) and taxable earnings, divided by total assets; Debt is the proxy for indebtedness, calculated as the ratio between net debt and total assets; $R O A$ is the proxy for profitability, calculated as the ratio between net income and total assets; $\alpha$ is the intercept of the regression. Discrepant observations ("outliers") were excluded based on the Bonferroni test, with 5\% significance. The values of the $t$ statistics are in parentheses. The estimations of the standard deviations (for the $t$ calculation) were robust to heteroscedasticity of the residuals. The significance level is $0.1 \%$ for ${ }^{* * *} ; 1 \%$ for ${ }^{* *}, 5 \%$ for ${ }^{*}$, and $10 \%$ for ${ }^{+}$.

Source: Elaborated by the authors.

Table 3 also shows a negative moderating effect of indebtedness over the absolute value of the BTD after IFRS adoption; that is, the impact of IFRS adoption over the absolute value of the BTD was negatively correlated with financial leverage.

Table 3

Result of the regression, for the IFRS adoption event, of the model given by Equation (8)

\begin{tabular}{|c|c|c|c|c|c|c|}
\hline $\begin{array}{l}\text { Equation (8) } \\
A b s\left(B T D_{i . t}\right)=\end{array}$ & $\left.B T D_{i, t-1}\right)$ & $+\delta_{2} R O A_{i}$ & $g_{i, t-1}+e_{i}$ & & & \\
\hline Variable & & dow & Thr & dow & & dow \\
\hline$\rho$ & 0.007 & $(4.13)^{* * *}$ & 0.009 & $(5.40)^{* * *}$ & 0.010 & $(4.99)^{* * *}$ \\
\hline $\mathrm{Abs}(\mathrm{BTD})_{\mathrm{t}-1}$ & 0.357 & $(4.16)^{* * *}$ & 0.170 & $(2.51)^{*}$ & 0.409 & $(3.90)^{* * *}$ \\
\hline Debtt-1 & -0.005 & $(-2.16)^{*}$ & -0.006 & $(-1.35)$ & 0.001 & $(0.20)$ \\
\hline $\mathrm{ROA}_{\mathrm{t}-1}$ & 0.023 & $(1.52)$ & 0.003 & $(0.25)$ & -0.005 & $(-0.35)$ \\
\hline Tang $_{\mathrm{t}-1}$ & -0.001 & $(-0.42)$ & 0.002 & $(0.71)$ & -0.002 & $(-0.41)$ \\
\hline $\mathrm{n}$ & 142 & & 135 & & 145 & \\
\hline $\mathrm{F}$ & 13.3 & & 3.7 & & 13.3 & \\
\hline $\mathrm{R}^{2}$ & 0.279 & & 0.103 & & 0.275 & \\
\hline
\end{tabular}

Note: $A b s(B T D)$ is the absolute value of the book-tax difference, calculated as the difference between earnings before income tax $(E B I T)$ and taxable earnings, divided by total assets; Debt is the proxy for indebtedness, calculated as the ratio between net debt and total assets; ROA is the proxy for profitability, calculated as the ratio between net income and total assets; $\rho$ is the intercept of the regression. Discrepant observations ("outliers") were excluded based on the Bonferroni test, with 5\% significance. The standard deviation estimations (for the $t$ calculation) were robust to heteroscedasticity of the residuals. The values of the $t$ statistics are in parentheses. The estimations of the standard deviations (for the $t$ calculation) were robust to heteroscedasticity of the residuals. The significance level is $0.1 \%$ for ***; $1 \%$ for **, $5 \%$ for * , and $10 \%$ for ${ }^{*}$.

Source: Elaborated by the authors. 
These results would be consistent with the idea that more indebted companies would have greater transparency, since they are more dependent on the capital market, as proposed by Daske, Hail, Leuz, and Verdi (2013). As they are more committed to transparency, these companies would not significantly alter their practices with the change of standard.
Hypothesis 2 is not supported by the results of tables 3 and 4 , which do not indicate a significant positive effect of profitability (ROA) over the BTD with IFRS adoption. The absence of statistical significance for bigger windows may derive from the use of the level of the ROA variable before the IFRS adoption event, which sought to avoid endogeneity due to simultaneity.

Table 4

Result of the regression, for the IFRS adoption event, of the model given by Equation (7)

\begin{tabular}{|c|c|c|c|c|c|c|}
\hline \multicolumn{7}{|c|}{$\begin{array}{l}\text { Equation (7): } \\
B T D_{i, t}=\rho+\phi_{1} B T D_{i, t-1}+\delta_{1} \operatorname{Debt}_{i, t-1}+\delta_{2} R O A_{i, t-1}+\delta_{3} \operatorname{Tang}_{i, t-1}+u_{i}\end{array}$} \\
\hline \multirow{2}{*}{$\begin{array}{l}\text { Variable } \\
\rho\end{array}$} & \multicolumn{2}{|c|}{ One-year window } & \multicolumn{2}{|c|}{ Three-year window } & \multicolumn{2}{|c|}{ Five-year window } \\
\hline & 0.007 & $(3.03)^{* * *}$ & 0.001 & $(0.42)$ & -0.001 & $(-0.35)$ \\
\hline BTD $_{\mathrm{t}-1}$ & 0.535 & $(5.42)^{* * *}$ & 0.406 & $(3.82)^{* * *}$ & 0.388 & $(3.38)^{* * *}$ \\
\hline Debt $-1_{1}$ & 0.002 & $(0.42)$ & -0.007 & $(-0.75)$ & -0.017 & $(-1.75)^{+}$ \\
\hline $\mathrm{ROA}_{\mathrm{t}-1}$ & 0.004 & $(0.21)$ & 0.019 & $(0.88)$ & 0.025 & $(0.98)$ \\
\hline Tang $_{\mathrm{t}-1}$ & -0.010 & $(-2.46)^{*}$ & 0.003 & $(0.51)$ & 0.000 & $(-0.01)$ \\
\hline $\mathrm{n}$ & 143 & & 138 & & 146 & \\
\hline $\mathrm{F}$ & 34.4 & & 16.0 & & 11.3 & \\
\hline $\mathrm{R}^{2}$ & 0.499 & & 0.345 & & 0.243 & \\
\hline
\end{tabular}

Note: BTD is the book-tax difference, calculated as the difference between earnings before income tax (EBIT) and taxable earnings, divided by total assets; Debt is the proxy for indebtedness, calculated as the ratio between net debt and total assets; $R O A$ is the proxy for profitability, calculated as the ratio between net income and total assets; $\rho$ is the intercept of the regression. Discrepant observations ("outliers") were excluded based on the Bonferroni test, with $5 \%$ significance. The values of the $t$ statistics are in parentheses. The estimations of the standard deviations (for the $t$ calculation) were robust to heteroscedasticity of the residuals. The significance level is $0.1 \%$ for ${ }^{* * *} ; 1 \%$ for ${ }^{* *}, 5 \%$ for ${ }^{*}$, and $10 \%$ for ${ }^{+}$.

Source: Elaborated by the authors.

Table 2 also partially supports hypothesis 3 , in that company size would have a negative moderating effect over variations in the absolute value of the BDT with IFRS adoption. Hypothesis 3 would also be aligned with the results of Ferreira, Martinez, Costa, and Passamani (2012), Joia and Nakao (2014), and Braga (2017), who identify a negative relationship between size and discrepancies between book and taxable income in Brazil. This effect is significant in the one- and five-year windows, but with a $p$-value of $6.2 \%$ in the five-year window. This result is inconsistent with the assumption of Daske, Hail, Leuz, and Verdi (2013), according to whom, just like the most indebted companies, bigger companies, because they have greater difficulty financing themselves with related agents due to the financial volumes involved, would have greater dependence in relation to the financial market, which would demand greater transparency even before IFRS adoption. What we observe is a tendency for book and taxable income to converge, in order to avoid greater scrutiny from the Internal Revenue Service.

\section{RESULTS IN THE END OF THE RTT EVENT}

Table 5 is similar to Table 1, containing descriptive statistics for the periods before and after the end of the RTT event. Here, however, there is the indication of a reduction in the $\mathrm{BTD}$, with the end of the $\mathrm{RTT}$, while at the same time there is an increase in the standard deviation. 
Table 5

Descriptive statistics in the periods before and after (Post) the end of the RTT event

\begin{tabular}{|c|c|c|c|c|c|c|c|}
\hline \multirow[b]{2}{*}{ Variable } & \multirow[b]{2}{*}{ Statistic } & \multicolumn{2}{|c|}{ One-year window } & \multicolumn{2}{|c|}{ Three-year window } & \multicolumn{2}{|c|}{ Five-year window } \\
\hline & & RTT & Post-RTT & RTT & Post-RTT & RTT & Post-RTT \\
\hline \multirow{2}{*}{ BTD } & mean & -0.005 & -0.009 & -0.003 & -0.019 & 0.002 & -0.016 \\
\hline & st. dev. & 0.043 & 0.051 & 0.042 & 0.160 & 0.030 & 0.153 \\
\hline \multirow{2}{*}{ Debt } & mean & 0.178 & 0.195 & 0.179 & 0.216 & 0.149 & 0.194 \\
\hline & st. dev. & 0.252 & 0.283 & 0.232 & 0.418 & 0.244 & 0.414 \\
\hline \multirow{2}{*}{ ROA } & mean & 0.057 & 0.048 & 0.069 & 0.011 & 0.080 & 0.015 \\
\hline & st. dev. & 0.130 & 0.135 & 0.143 & 0.453 & 0.132 & 0.431 \\
\hline \multirow{2}{*}{ Tang } & mean & 0.215 & 0.213 & 0.232 & 0.217 & 0.228 & 0.204 \\
\hline & st. dev. & 0.208 & 0.205 & 0.218 & 0.209 & 0.215 & 0.197 \\
\hline \multirow{2}{*}{$\log (\mathrm{TA})$} & mean & 22.169 & 22.217 & 22.202 & 22.279 & 22.063 & 22.266 \\
\hline & st. dev. & 1.635 & 1.691 & 1.583 & 1.690 & 1.555 & 1.719 \\
\hline
\end{tabular}

Note: BTD is the book-tax difference, calculated as the difference between earnings before income tax (EBIT) and taxable earnings, divided by total assets; Debt is the proxy for indebtedness, calculated as the ratio between net debt and total assets; $R O A$ is the proxy for profitability, calculated as the ratio between net income and total assets; Tang is the proxy for tangibility of assets, calculated as the ratio between fixed assets and total assets; $\log (T A)$ is the proxy for size, calculated as the logarithm of total assets.

Source: Elaborated by the authors.

Table 6 is similar to Table 2 . In it, there is an indication of reconvergence between book and taxable income with the end of the RTT, through the negative and significant sign (in the one-year window) of the intercept $(\alpha)$. Equally, for the size effect, in Table 6 we observe symmetrical variations to those in Table 2, due to the inversion of the effects over the BTD with the reconvergence of the standards due to the end of the RTT. Since for this oneyear window the intercept $(\alpha)$ is negative, the positive coefficient of the size variable indicates that the BTD would decrease less for bigger companies, after the standards reconverged. Despite only being significant in the one-year window, this is consistent with bigger companies using the flexibility of the IFRS to reduce the BTD, in order to reduce the attention of the tax authorities. In fact, with the convergence of the standards, reducing this flexibility, the variation in the difference between taxable and book income (BTD) has a negative relationship with size.

Table 6

Result of the regression, for the end of the RTT event, of the model given by Equation (9)

\begin{tabular}{|c|c|c|c|c|c|c|}
\hline \multicolumn{7}{|c|}{$\begin{array}{l}\text { Equation (9): } \\
\qquad \log \left(\frac{\operatorname{Abs}\left(B T D_{i, t}\right)}{\operatorname{Abs}\left(B T D_{i, t-1}\right)}\right)=\alpha+\beta_{1} \operatorname{Debt}_{i, t-1}+\beta_{2} \text { Size }_{i, t-1}+\beta_{3} \operatorname{Tang}_{i, t-1}+u_{i}\end{array}$} \\
\hline Variable & \multicolumn{2}{|c|}{ One-year window } & \multicolumn{2}{|c|}{ Three-year window } & \multicolumn{2}{|c|}{ Five-year window } \\
\hline$\alpha$ & -2.96 & $(-2.10)^{*}$ & -1.73 & $(-1.26)$ & -0.87 & $(-0.71)$ \\
\hline Debt $-1_{1}$ & 0.37 & $(0.73)$ & 1.39 & $(0.80)$ & 0.19 & $(0.49)$ \\
\hline Size $_{\mathrm{t}-1}$ & 0.13 & $(2.00)^{*}$ & 0.08 & $(1.22)$ & 0.04 & $(0.74)$ \\
\hline Tang $_{\mathrm{t}-1}$ & 0.56 & $(0.99)$ & 0.66 & $(1.43)$ & 0.57 & $(1.37)$ \\
\hline $\mathrm{n}$ & 161 & & 147 & & 162 & \\
\hline $\mathrm{F}$ & 2.4 & & 7.1 & & 1.5 & \\
\hline $\mathrm{R}^{2}$ & 0.043 & & 0.164 & & 0.027 & \\
\hline
\end{tabular}

Note: $A b s(B T D)$ is the absolute value of the book-tax difference, calculated as the difference between earnings before income tax (EBIT) and taxable earnings, divided by total assets; Debt is the proxy for indebtedness, calculated as the ratio between net debt and total assets; ROA is the proxy for profitability, calculated as the ratio between net income and total assets; $\alpha$ is the intercept of the regression. Discrepant observations ("outliers") were excluded based on the Bonferroni test, with 5\% significance. The values of the $t$ statistics are in parentheses. The significance level is $0.1 \%$ for ${ }^{* *} ; 1 \%$ for $* *, 5 \%$ for $*$, and $10 \%$ for ${ }^{+}$.

Source: Elaborated by the authors.

In Table 6, however, there is not this symmetry for the effect of indebtedness, as the coefficients of Debt $t_{t-1}$ are not significant, although they are positive. This indicates that the variations observed in Table 2, related to indebtedness, would not derive from the objective application of different standards when calculating recurrent earnings for the 
capital market and for tax purposes, but possibly from the continued use of procedures already aligned with the principles of the IFRS, which attenuated the effects of IFRS adoption.

Table 7

Result of the regression, for the end of the RTT event, of the model given by Equation (8)

\begin{tabular}{|c|c|c|c|c|c|c|}
\hline \multicolumn{7}{|c|}{$\begin{array}{l}\text { Equation (8): } \\
A \operatorname{Abs}\left(B T D_{i, t}\right)=\rho+\phi_{1} \operatorname{Abs}\left(B T D_{i, t-1}\right)+\delta_{1} \operatorname{Debt}_{i, t-1}+\delta_{2} R O A_{i, t-1}+\delta_{3} \operatorname{Tang}_{i, t-1}+e_{i}\end{array}$} \\
\hline \multirow{2}{*}{ Variable } & \multicolumn{2}{|c|}{ One-year window } & \multicolumn{2}{|c|}{ Three-year window } & \multicolumn{2}{|c|}{ Five-year window } \\
\hline & 0.01 & $(2.60)^{*}$ & 0.01 & $(4.13)^{* * *}$ & 0.01 & $(5.57)^{* * *}$ \\
\hline $\mathrm{Abs}(\mathrm{BTD})_{\mathrm{t}-1}$ & 0.21 & $(2.83)^{* *}$ & 0.33 & $(2.22)^{*}$ & 0.37 & $(3.16)^{* *}$ \\
\hline Debtt-1 $_{1}$ & 0.01 & $(1.22)$ & 0.01 & $(1.38)$ & 0.01 & $(1.18)$ \\
\hline $\mathrm{ROA}_{\mathrm{t}-1}$ & 0.04 & $(2.02)^{*}$ & -0.02 & $(-0.74)$ & -0.03 & $(-1.76)^{+}$ \\
\hline Tang $_{\mathrm{t}-1}$ & 0.00 & $(0.30)$ & -0.01 & $(-1.01)$ & 0.00 & $(0.15)$ \\
\hline $\mathrm{n}$ & 153 & & 138 & & 151 & \\
\hline $\mathrm{F}$ & 3.9 & & 7.9 & & 7.1 & \\
\hline $\mathrm{R}^{2}$ & 0.096 & & 0.193 & & 0.164 & \\
\hline
\end{tabular}

Note: $A b s(B T D)$ is the absolute value of the book-tax difference, calculated as the difference between earnings before income tax (EBIT) and taxable earnings, divided by total assets; Debt is the proxy for indebtedness, calculated as the ratio between net debt and total assets; ROA is the proxy for profitability, calculated as the ratio between net income and total assets; $\rho$ is the intercept of the regression. Discrepant observations ("outliers") were excluded based on the Bonferroni test, with 5\% significance. The values of the $t$ statistics are in parentheses. The significance level is $0.1 \%$ for $* * * ; 1 \%$ for **, $5 \%$ for *, and $10 \%$ for ${ }^{+}$.

Source: Elaborated by the authors.

Table 7 is similar to Table 3. Just like Table 6, it indicates that indebtedness did not alter the impact of the end of the RTT over the convergence of book and taxable income. With relation to profitability, the results are conflicting, with a positive and significant moderating effect in the one-year window, but a negative effect in bigger windows, with a $8.1 \%$ significance level in the five-year window.

Table 8 is similar to Table 4 . In it, we see that leverage had a negative moderating effect over the nominal value (with a sign) of the BTD, at the end of the RTT. As Table 6 did not present any effect of indebtedness over the variation in the absolute value of the $\mathrm{BTD}$, this can be interpreted as a negative relationship between leverage and taxable earnings, as an increase in the former reduces the nominal value of the BTD. This is consistent with the assumption that more leveraged companies were already and remained more transparent, to facilitate their access to the capital market. The less leveraged companies, in turn, may have sought to depress their taxable earnings, with the aim of avoiding paying taxes, for example, by delaying the recognition of losses until the end of the RTT.

Table 8

Result of the regression, for the end of the RTT event, of the model given by Equation (7)

\begin{tabular}{|c|c|c|c|c|c|c|}
\hline \multicolumn{7}{|c|}{$\begin{array}{l}\text { Equation (7): } \\
B T D_{i, t}=\rho+\phi_{1} B T D_{i, t-1}+\delta_{1} \mathrm{Debt}_{i, t-1}+\delta_{2} R O A_{i, t-1}+\delta_{3} \operatorname{Tang}_{i, t-1}+u_{i}\end{array}$} \\
\hline \multirow{2}{*}{$\begin{array}{l}\text { Variable } \\
\rho\end{array}$} & \multicolumn{2}{|c|}{ One-year window } & \multicolumn{2}{|c|}{ Three-year window } & \multicolumn{2}{|c|}{ Five-year window } \\
\hline & 0.01 & $(0.73)$ & 0.00 & $(-0.70)$ & -0.00 & $(-1.11)$ \\
\hline $\mathrm{BTD}_{\mathrm{t}-1}$ & 0.28 & $(2.00)^{*}$ & 0.41 & $(2.33)^{*}$ & 0.44 & $(4.07)^{* * *}$ \\
\hline Debt $-1_{1}$ & -0.04 & $(-1.93)^{+}$ & -0.02 & $(-3.64)^{* * *}$ & -0.02 & $(-3.09)^{* *}$ \\
\hline $\mathrm{ROA}_{\mathrm{t}-1}$ & -0.05 & $(-0.89)$ & 0.01 & $(0.28)$ & 0.05 & $(2.35)^{*}$ \\
\hline Tang $_{\mathrm{t}-1}$ & 0.00 & $(0.13)$ & 0.01 & $(1.88)^{+}$ & 0.01 & $(0.84)$ \\
\hline $\mathrm{n}$ & 158 & & 137 & & 150 & \\
\hline $\mathrm{F}$ & 7.7 & & 23.6 & & 24.6 & \\
\hline $\mathrm{R}^{2}$ & 0.167 & & 0.417 & & 0.404 & \\
\hline
\end{tabular}

Note: BTD is the book-tax difference, calculated as the difference between earnings before income tax (EBIT) and taxable earnings, divided by total assets; Debt is the proxy for indebtedness, calculated as the ratio between net debt and total assets; ROA is the proxy for profitability, calculated as the ratio between net income and total assets; $\rho$ is the intercept of the regression. Discrepant observations ("outliers") were excluded based on the Bonferroni test, with 5\% significance. The values of the $t$ statistics are in parentheses. The estimations of the standard deviations (for the $t$ calculation) were robust to heteroscedasticity of the residuals. The significance level is $0.1 \%$ for ${ }^{* * *} ; 1 \%$ for ${ }^{* *}, 5 \%$ for ${ }^{*}$, and $10 \%$ for ${ }^{+}$.

Source: Elaborated by the authors. 


\section{CONCLUSIONS}

There are conflicting results in the literature regarding the influence of the IFRS on earnings management. This study proposes that this conflict may derive from the fact that the effects of IFRS adoption are not the same for all companies, depending on the incentives of each company to manage earnings. The aim of this study was to verify if, and how, indebtedness, profitability, and size, taken as variables related with incentives to manage earnings, moderated the effect of IFRS adoption and, then, the effect of the end of the RTT over earnings management, using the BTD as a proxy.

The results of this study indicate a negative relationship between indebtedness and the absolute value of the BTD after IFRS adoption. This result is inconsistent with the assumption that more indebted companies would manage their earnings more, with the aim of improving their financial statements for investors (hypothesis 1). Therefore, the positive relationship between financial leverage and divergences between taxable and book income, observed in Brazilian companies by Braga (2017) and Joia and Nakao (2014), did not intensify with IFRS adoption.

We also observed negative moderation of indebtedness in relation to the nominal value of the BTD, with the end of the RTT. This indicates that the book value decreased in relation to the taxable value. Thus, considering that the tax rules did not vary in the first period analyzed (after IFRS adoption, but during the RTT), it can be said that, with the end of the RTT, less leveraged companies may have depressed their taxable earnings, in order to avoid paying taxes, increasing the nominal value of the BTD, while more leveraged companies maintained a higher level of transparency in their accounting statements, presenting a relative reduction in the nominal value of the BTD.

No consistent significant effect of profitability (ROA) was observed, whether with IFRS adoption or with the end of the RTT. Thus, there is no evidence in favor of hypothesis 2 .

Regarding the effect of size over the BTD, with the alterations in the standards, there is a negative effect with statistical significance at the generally accepted levels. With the end of the RTT, the effect of size over the variation in the BTD becomes positive, indicating the reversal of the bias, when the standards reconverge. These results, both relating to the IFRS adoption event, and to the end of the RTT event, are consistent with bigger companies using the flexibility of the principles-based standards (IFRS) with the aim of bringing taxable income closer to book income, to reduce the attention of the tax authorities (hypothesis 3).

In a general analysis, there is no evidence that the IFRS gave more discretion for companies to manage earnings. On the contrary, particularly in relation to the moderation by indebtedness, the results obtained here are more consistent with timely loss recognition, independently of its tax effect at the end of the RTT, unlike what would be expected if there was casuistic use of the greater discretion provided by the IFRS.

\section{REFERENCES}

Ahmed, A. S., Neel, M., \& Wang, D. (2013). Does mandatory adoption of IFRS improve accounting quality? Preliminary evidence. Contemporary Accounting Research, 30(4), 13441372. https://doi.org/10.2139/ssrn.1502909

Armstrong, C. S., Blouin, J. L., \& Larcker, D. F. (2012). The incentives for tax planning. Journal of Accounting and Economics, 53(1), 391-411. https://doi.org/10.1016/j. jacceco.2011.04.001

Atwood, T. J., Drake, M. S., Myers, J. N., \& Myers, L. A. (2012). Home country tax system characteristics and corporate tax avoidance: International evidence. The Accounting Review, 87(6), 1831-1860. https://doi.org/10.2139/ssrn.1594936

Badertscher, B. A., Phillips, J. D., Pincus, M., \& Rego, S. O. (2009). Earnings management strategies and the trade-off between tax benefits and detection risk: To conform or not to conform? The Accounting Review, 84(1), 63-97.
Ball, R., Li, X., \& Shivakumar, L. (2015). Contractibility and transparency of financial statement information prepared under IFRS: Evidence from debt contracts around IFRS adoption. Journal of Accounting Research, 53(5), 915-963. http://dx.doi.org/10.2139/ssrn.997065

Barth, M. E., Landsman, W. R., \& Lang, M. H. (2008). International accounting standards and accounting quality. Journal of Accounting Research, 46(3), 467-498.

Bartov, E., Goldberg, S. R., \& Kim, M. (2005). Comparative value relevance among German, U.S., and international accounting standards: A German stock market perspective. Journal of Accounting, Auditing \& Finance, 20(2), 95-119. https://doi. org/10.1111/j.1475-679X.2008.00287.x

Black, R., \& Nakao, S. H. (2017). Heterogeneidade na qualidade do lucro contábil entre diferentes classes de empresas com a adoção de IFRS: Evidências do Brasil. Revista Contabilidade 
\& Finanças, 28(73), 113-131. https://doi.org/10.1590/1808057x201702750

Blaylock, B., Gaertner, F., \& Shevlin, T. (2015). The association between book-tax conformity and earnings management. Review of Accounting Studies, 20(1), 141-172. https://doi. org/10.2139/ssrn.1983107

Braga, R. N. (2017). Efeitos da adoção das IFRS sobre o tax avoidance. Revista Contabilidade \& Finanças, 28(75), 407-424. https://doi.org/10.1590/1808-057x201704680

Byard, D., Li, Y., \& Yu, Y. (2011). The effect of mandatory IFRS adoption on financial analysts' information environment. Journal of Accounting Research, 49(1), 69-96. https://doi. org/10.1111/j.1475-679X.2010.00390.x

Capkun, V., Collins, D., \& Jeanjean, T. (2016). The effect of IAS/ IFRS adoption on earnings management (smoothing): A closer look at competing explanations. Journal of Accounting and Public Policy, 35(4), 352-394. https://doi.org/10.1016/j. jaccpubpol.2016.04.002

Cavalier-Rosa, G., \& Tiras, S. L. (2013). Brazil's adoption of IFRS: Fertile ground for examining earnings management. Brazilian Business Review, 10(4), 133-146. https://doi.org/10.15728/ bbr.2013.10.4.6

Chan, K. H., Lin, K. Z., \& Mo, P. L. L. (2010). Will a departure from tax-based accounting encourage tax noncompliance? Archival evidence from a transition economy. Journal of Accounting and Economics, 50(1), 58-73. https://doi. org/10.1016/j.jacceco.2010.02.001

Christensen, H. B., Hail, L., \& Leuz, C. (2013). Mandatory IFRS reporting and changes in enforcement. Journal of Accounting and Economics, 56(2-3, Supplement 1), 147-177. https://doi. org/10.1016/j.jacceco.2013.10.007

Christensen, H. B., Lee, E., \& Walker, M. (2007). Cross-sectional variation in the economic consequences of international accounting harmonization: The case of mandatory IFRS adoption in the UK. The International Journal of Accounting, 42(4), 341-379. https://doi.org/10.1016/j.intacc.2007.09.007

Christensen, H. B., Lee, E., Walker, M., \& Zeng, C. (2015). Incentives or standards: What determines accounting quality changes around IFRS adoption? European Accounting Review, 24(1), 31-61. https://doi.org/10.1080/09638180.201 5.1009144

Comissão de Valores Imobiliários. (2007). Instrução normativa 457, de 13 de julho de 2007. http://conteudo.cvm.gov. br/export/sites/cvm/legislacao/instrucoes/anexos/400/ inst 457 consolid.pdf

Comitê de Pronunciamentos Contábeis. (2008a). CPC 00 R1 - Estrutura Conceitual para Elaboração e Divulgação de Relatório Contábil-Financeiro. http://static.cpc.aatb.com.br/ Documentos/147_CPC00_R1.pdf

Comitê de Pronunciamentos Contábeis. (2008b). CPC 12 - Ajuste a Valor Presente 2, de 5 de dezembro de 2008. http://static.cpc. aatb.com.br/Documentos/219_CPC_12.pdf

Comitê de Pronunciamentos Contábeis. (2008c). CPC 14 Instrumentos Financeiros: Reconhecimento, Mensuração e Evidenciação. http://static.cpc.aatb.com.br/Documentos/226_ Termo_de_aprovacao_CPC_14.pdf
Comitê de Pronunciamentos Contábeis. (2010a). CPC 01 R1 Redução ao Valor Recuperável de Ativos, 2010. http://static. cpc.aatb.com.br/Documentos/27_CPC_01_R1_rev\%2012.pdf

Comitê de Pronunciamentos Contábeis. (2010b). CPC 04 R1 - Ativo Intangível. http://static.cpc.aatb.com.br/ Documentos/187_CPC_04_R1_rev\%2013.pdf

Comitê de Pronunciamentos Contábeis. (2012). CPC 46 Mensuração do Valor Justo, de 20 de dezembro de 2012. http://static.cpc.aatb.com.br/Documentos/395_CPC_46_ rev\%2012.pdf

Comitê de Pronunciamentos Contábeis. (2017). CPC 06 R2 - Operações de Arrendamento Mercantil, de 6 de outubro de 2017. http://static.cpc.aatb.com.br/Documentos/533_ CPC_06_(R2).pdf

Daske, H., Hail, L., Leuz, C., \& Verdi, R. (2008). Mandatory IFRS reporting around the world: Early evidence on the economic consequences. Journal of Accounting Research, 46(5), 10851142. https://doi.org/10.1111/j.1475-679X.2008.00306.x

Daske, H., Hail, L., Leuz, C., \& Verdi, R. (2013). Adopting a label: Heterogeneity in the economic consequences around IAS/IFRS adoptions. Journal of Accounting Research, 51(3), 495-547. https://doi.org/10.1111/1475-679X.12005

Dechow, P. M. (1994). Accounting earnings and cash flows as measures of firm performance: The role of accounting accruals. Journal of Accounting and Economics, 18(1), 3-42. https://doi.org/10.1016/0165-4101(94)90016-7

Desai, M. A. (2005). The degradation of reported corporate profits. Journal of Economic Perspectives, 19(4), 171-192. https://doi.org/10.1257/089533005775196705

Ferreira, F. R., Martinez, A. L., Costa, F. M. da, \& Passamani, R. R. (2012). Book-tax differences e gerenciamento de resultados no mercado de ações do Brasil. Revista de Administração de Empresas, 52(5), 488-501. http://dx.doi.org/10.1590/S003475902012000500002

Fonseca, K. B. C., \& Costa, P. de S. (2017). Fatores determinantes das book-tax differences. Revista de Contabilidade e Organizações, 11(29), 17-29. https://doi.org/10.11606/rco. v11i29.122331

Grecco, M. C. P. (2013). The effect of Brazilian convergence to IFRS on earnings managment by listed Brazilian nonfinancial companies. Brazilian Business Review, 10(4), 110-132. https:// doi.org/10.15728/bbr.2013.10.4.5

Grecco, M. C. P., Geron, C. M. S., Grecco, G. B., \& Lima, J. P. C. (2014). The effect of IFRS on earnings management in Brazilian non-financial public companies. Emerging Markets Review, 21, 42-66.

Hagerman, R. L., \& Zmijewski, M. E. (1979). Some economic determinants of accounting policy choice. Journal of Accounting and Economics, 1(2), 141-161. https://doi. org/10.1016/0165-4101(79)90004-1

Hanlon, M. (2005). The persistence and pricing of earnings, accruals, and cash flows when firms have large book-tax differences. The Accounting Review, 80(1), 137-166. https:// doi.org/10.2139/ssrn.379140

Horton, J., Serafeim, G., \& Serafeim, I. (2013). Does mandatory IFRS adoption improve the information environment? 
Contemporary Accounting Research, 30(1), 388-423. https:// doi.org/10.1111/j.1911-3846.2012.01159.x

Hung, M., \& Subramanyam, K. R. (2007). Financial statement effects of adopting international accounting standards: The case of Germany. Review of Accounting Studies, 12(4), 623-657. https://doi.org/10.1007/s11142-007-9049-9

Huseynov, F., \& Klamm, B. K. (2012). Tax avoidance, tax management and corporate social responsibility. Journal of Corporate Finance, 18(4), 804-827. https://doi.org/10.1016/j. jcorpfin.2012.06.005

Jeanjean, T., \& Stolowy, H. (2008). Do accounting standards matter? An exploratory analysis of earnings management before and after IFRS adoption. Journal of Accounting and Public Policy, 27(6), 480-494. https://doi.org/10.1016/j. jaccpubpol.2008.09.008

Joia, R. M., \& Nakao, S. H. (2014). Adoção de IFRS e gerenciamento de resultado nas empresas brasileiras de capital aberto. Revista de Educação e Pesquisa em Contabilidade (REPeC), 8(1), 22-38. https://doi.org/10.17524/ repec.v8i1.1014

Law 6,404 of December $15^{\text {th }}$ of 1976. (1976). Discusses Joint-Stock Companies. http://www.planalto.gov.br/ccivil_03/LEIS/ L6404consol.htm

Law 11,638 of December $28^{\text {th }}$ of 2007. (2007). Alterations, arrangements, corporation law. http://www.planalto.gov.br/ ccivil_03/_Ato2007-2010/2007/Lei/L11638.htm.

Law 11,941 of May 27th of 2009. (2009). Alters the federal tax legislation. http://www.planalto.gov.br/ccivil_03/_Ato20072010/2009/Lei/L11941.htm.

Law 12,973 of May 13 ${ }^{\text {th }}$ of 2014. (2014). Alters the federal tax legislation. http://www.planalto.gov.br/ccivil_03/_Ato20112014/2014/Lei/L12973.htm.

Macedo, M. A. da S., Machado, M. R., Machado, M. A. V., \& Mendonça, P. H. C. (2013). Impacto da convergência às normas contábeis internacionais no Brasil sobre o conteúdo informacional da contabilidade. Revista de Educação e Pesquisa em Contabilidade (REPeC), 7(3), 222-239. https:// doi.org/10.17524/repec.v7i3.905

Marques, A. V. C., Costa, P. de S., \& Silva, P. R. (2016). Relevância do conteúdo informacional das book-tax differences para previsão de resultados futuros: evidências de países-membros da América Latina. Revista Contabilidade \& Finanças, 27(70), 29-42. https://doi.org/10.1590/1808-057x201501570

Mendes, C. J. F., \& Freire, F. de S. (2014). A governança corporativa e manipulação de informação contábil: mensuração a valor justo nos bancos comerciais. Revista
Contemporânea de Contabilidade, 11(23), 53-76. https://doi. org/10.5007/2175-8069.2014v11n23p53

Mills, L. F. (1998). Book-tax differences and internal revenue service adjustments. Journal of Accounting Research, 36(2), 343-356. https://doi.org/10.2307/2491481

Mills, L. F., \& Newberry, K. J. (2005). Firms' off-balance sheet and hybrid debt financing: Evidence from their book-tax reporting differences. Journal of Accounting Research, 43(2), 251-282. https://doi.org/10.1111/j.1475-679x.2005.00170.x

Morais, H. C. B., \& Macedo, M. A. D. S. (2021). Relação entre gerenciamento de resultado e abnormal book-tax differences no Brasil. Revista Contabilidade \& Finanças, 32(85), 46-64. https://doi.org/10.1590/1808-057x202009230

Nakao, S. H., \& Gray, S. J. (2018). The impact of IFRS in Brazil: The legacy of mandatory book-tax conformity. Australian Accounting Review, 28(4), 482-495. https://doi.org/10.1111/ auar. 12223

Santos, M. A. C. dos, \& Cavalcante, P. R. N. (2014). O efeito da adoção dos IFRS sobre a relevância informacional do lucro contábil no Brasil. Revista Contabilidade \& Finanças, 25(66), 228-241. https://doi.org/10.1590/1808-057x201410690

Silva, C. L. P. M. da, Santos, M. A. C. dos, Koga, G. H., Barbosa, R. A. C. (2014). Tributação e IFRS no Brasil: Alterações na legislação do IRPJ, da CSLL, do PIS/Pasep e da Cofins, trazidas pela lei $n^{\circ} 12.973 / 2014$. Revista da Receita Federal: estudos tributários e aduaneiros, 1(1), 393-422.

Silva, R. L. M. da, \& Nardi, P. C. C. (2017). Full adoption of IFRSs in Brazil: Earnings quality and the cost of equity capital. Research in International Business and Finance, 42(Supplement C), 1057-1073. https://doi.org/10.1016/j. ribaf.2017.07.041

Sweeney, A. P. (1994). Debt-covenant violations and managers' accounting responses. Journal of Accounting and Economics, 17(3), 281-308. https://doi.org/10.1016/0165-4101(94)90030-2

Tang, T., \& Firth, M. (2011). Can book-tax differences capture earnings management and tax management? Empirical evidence from China. The International Journal of Accounting, 46(2), 175-204. https://doi.org/10.1016/j.intacc.2011.04.005

Wilson, R. J. (2009). An examination of corporate tax shelter participants. The Accounting Review, 84(3), 969-999. https:// doi.org/10.2308/accr.2009.84.3.969

Wooldridge, J. M. (2001). Econometric analysis of cross section and panel data. MIT press.

Zimmerman, J. L. (1983). Taxes and firm size. Journal of Accounting and Economics, 5, 119-149. https://doi. org/10.1016/0165-4101(83)90008-3 